Sex-specific competition differently regulates ecophysiological responses and phytoremediation of Populus cathayana under $\mathrm{Pb}$ stress

Chen, Juan

2017-12

Chen , J , Han , Q, Duan , B , Korpelainen , H \& Li , C 2017 , ' Sex-specific competition differently regulates ecophysiological responses and phytoremediation of Populus cathayana under Pb stress ' , Plant and Soil , vol. 421 , no. 1-2 , pp. 203-218 . https://doi.org/10.1007/s11104-017-3450-3

http://hdl.handle.net/10138/307672

https://doi.org/10.1007/s11104-017-3450-3

unspecified

acceptedVersion

Downloaded from Helda, University of Helsinki institutional repository.

This is an electronic reprint of the original article.

This reprint may differ from the original in pagination and typographic detail.

Please cite the original version. 


\title{
Sex-specific competition differently regulates ecophysiological responses and phytoremediation of Populus cathayana under $\mathbf{P b}$ stress
}

\author{
Juan Chen • Qingquan Han • Baoli Duan • Helena Korpelainen • Chunyang Li
}

Received: 19 June 2017 / Accepted: 28 September 2017 / Published online: 10 October 2017

(C) Springer International Publishing AG 2017

\begin{abstract}
Background and aims Lead $(\mathrm{Pb})$ contamination seriously threatens agroforestry production and safety. We aim to determine the interactive influence of $\mathrm{Pb}$ and sexual competition on the growth performance, photosynthetic and biochemical traits, ultrastructure and phytoremediationrelated parameters of males and females.

Methods In the present study, eco-physiological responses and phytoremediation traits of Populus cathayana females and males were evaluated under interactive treatments of $\mathrm{Pb}$ and competition.

Results There were significant sex-specific competition effects on biomass partition, photosynthetic activities, carbohydrate contents, nitrogen and phosphorus use
\end{abstract}

Responsible Editor: Henk Schat

J. Chen $\cdot$ Q. Han $\cdot$ B. Duan

Key Laboratory of Mountain Surface Processes and Ecological Regulation, Chinese Academy of Sciences, Institute of Mountain Hazards and Environment, Chengdu 610041, China

e-mail: licy@hznu.edu.cn

\section{J. Chen}

Sichuan Province Key Laboratory of Ecological Security and Protection, Mianyang Normal University, Mianyang 621000 , China

\section{C. $\mathrm{Li}$}

College of Life and Environmental Sciences, Hangzhou Normal University, 310036 Hangzhou, China

\section{H. Korpelainen}

Department of Agricultural Sciences, Viikki Plant Science Centre, University of Helsinki, P.O. Box 27, Helsinki FI-00014, Finland efficiencies, ultrastructure and phytoremediation under $\mathrm{Pb}$ stress. When competition within the same sex was compared, females were more sensitive to $\mathrm{Pb}$ stress, while males possessed greater $\mathrm{Pb}$ contents, and a higher bioconcentration factor and tolerance index. Under inter-sexual competition, males alleviated competition effects through greater $\mathrm{Pb}$ absorption, and lower photosynthetic rates, nutrient use efficiencies and biomass accumulation. Moreover, $\mathrm{Pb}$ stress altered competition intensities of both sexes.

Conclusions Sex-specific competition and neighbor effects may regulate responses and phytoremediation under heavy metal stress in dioecious plants. In the future, more attention should be paid on the effects of inter- and intrasexual competition on dioecious species in the process of forestation and restoration of contaminated soil.

Keywords Dioecy $\cdot$ Competition $\cdot$ Lead $\cdot$ Photosynthetic capacity Phosphorus and nitrogen use efficiency .

Carbohydrates

\section{Introduction}

Dioecy exists in 157 flowering plant families and about $6 \%$ of the 240,000 angiosperm species are dioecious (Renner and Ricklefs 1995). It is well known that spatial segregation of the sexes (SSS) is associated with microhabitat differences in dioecious species (Onyekwelu and Harper 1979; Korpelainen 1991; Dudley 2006; Li et al. 2007). Females are more common in favorable habitats, while males are more common in habitats with limited 
resources (Dawson and Ehleringer 1993; Stehlik et al. 2008). Many morphological, physiological and ecological differences between sexes have been observed in dioecious plants under environmental stresses, including, e.g., drought, salinity, nutrient deficiency and heavy metal stress (Xu et al. 2008; Chen et al. 2010; Chen et al. 2011; Zhang et al. 2014; Juvany and Munné-Boch 2015). However, these sex-related studies have rarely considered biotic factors, such as competition. Competition causes significant effects on plant growth, species diversity, community structures and nutrient cycles in local ecosystems. The type of plant-plant competition (positive, negative or neutral) frequently shifts along with different environmental factors (Fargione et al. 2003; Liancourt et al. 2005; Maestre et al. 2009). Tilman's competition theory (1982) suggests that competition is stronger at low nutrient levels rather than at high nutrient levels, while the stress gradient hypothesis (SGH) suggests that plants may negatively compete for resources in a productive environment but may positively compete with neighbors in a severe environment (Bertness and Callaway 1994).

The classic ecological niche theory predicts that the real niche is always smaller than the fundamental niche due to competitive effects (Dybzinski and Tilman 2007; Bloor et al. 2008). Herrera (1988) observed that sexspecific competition of Osyris quadripartite is asymmetrical, and males are inhibited more when competing with neighboring females. Nanami et al. (2005) showed that both intra- and inter-sexual competition effects on growth rates are significant in female Podocarpus nagi trees, while Sánchez-Vilas et al. (2011) found that both intra- and inter-sexual competition affect the aboveground growth of males but not the growth of females in Mercurialis annua. Therefore, sexrelated responses to competition are species-specific, possibly related to the presence of neighboring competitors (Nanami et al. 2005; Zhang et al. 2009) and to given environmental conditions (Eppley 2006). However, sex-related competitive interactions and neighbor effects under abiotic stresses have been largely neglected in studies on dioecious plants (Herrera 1988; Eppley 2006; Rogers and Eppley 2012). Moreover, previous studies have mostly focused on changes in growth and morphology instead of exploring intrinsic physiological processes under different competition patterns (Nicotra 1999; Eppley 2006).
Heavy metals seriously threaten the growth and survival of plants and there may be special consequences on dioecious species with sex-specific responses (Chen et al. 2011; Han et al. 2013; Jiang et al. 2013). Lead (Pb) contamination has become a serious problem in agroforestry production and safety in China due to high toxicity and long-lasting persistence in soil (Shahid et al. 2011). Recent studies have indicated that some dioecious trees have potential for phytoremediation, i.e. removal of soil contaminants (Han et al. 2013; He et al. 2013; Ermakov et al. 2015; Qasim et al. 2016). However, it remains unclear, whether there are interactive effects between heavy metal stress and sexual competition on ecophysiological responses and phytoremediation traits of dioecious species. It is well known that intrinsic physiological processes as well as extrinsic growth traits can reflect the response mechanism of plants to heavy metal stress. Photosynthesis inhibition and damage to leaf ultrastructure are common symptoms of $\mathrm{Pb}$ toxicity (Kalaji and Loboda 2007; Islam et al. 2008; Han et al. 2013). Proper $\mathrm{N}$ application may alleviate toxic effect by increasing stromal proteins and photosynthetic capacity; moreover, non-structural carbohydrate storage can enhance plants' ability to resist stress conditions (Myers and Kitajima 2007; O'Brien et al. 2014). It is recognized that the bioconcentration factor $(\mathrm{BCF})$, translocation factor $(\mathrm{TF})$ and tolerance index (TI) can describe the extent of the phytoremediation ability (Baker et al. 1994; Zayed et al. 1998). Therefore, these ecophysiological parameters can be used as indexes to evaluate plant adaptation and phytoremediation under $\mathrm{Pb}$ stress.

Populus cathayana Rehd, a dioecious species widely distributed in China, has a high economical value and an important ecological role in local ecosystems. In the present study, we hypothesize that the responses of $P$. cathyana males and females under $\mathrm{Pb}$ stress might be affected by sexual competition, which may explain spatial segregation of sexes in heavy metal contaminated regions. To test these hypotheses, our study aims (i) to determine the interactive influence of $\mathrm{Pb}$ and sexual competition on the growth performance, photosynthetic and biochemical traits, ultrastructure and phytoremediation-related parameters of males and females, (ii) to evaluate, whether a specific sex of neighbors changes the responses and phytoremediation traits of $P$. cathayana under $\mathrm{Pb}$ stress, and (iii) to investigate, whether $\mathrm{Pb}$ stress changes competition intensities and interactions between the two sexes. 


\section{Materials and methods}

Experimental design

The experiment followed a completely randomized design with three factorial combinations, including sex, competition and $\mathrm{Pb}$ stress. Two $\mathrm{Pb}$ treatments $(0$, $500 \mu \mathrm{M}$ ), two sexes (females and males) and three competition patterns (female $\times$ female, FF; female $\times$ male, FM; male $\times$ male, MM) were employed. Twenty replicates per treatment were included in the experiment. On 19 March 2015, 240 healthy cuttings (120 females and 120 males) of $P$. cathayana were chosen and transplanted into $30-\mathrm{L}$ plastic pots filled with $25 \mathrm{Kg}$ homogenized brown soil (two cuttings per pot; two females, two males, or a female and a male). After 8 weeks of growth, the plants were subjected to $\mathrm{Pb}$ stress for 12 weeks. In the treatment, $\mathrm{Pb}$ was applied into soil by evenly adding $5.33 \mathrm{mmol}$ $\mathrm{L}^{-1} \mathrm{~Pb}\left(\mathrm{NO}_{3}\right)_{2}$ solution to the pots every day during the first 15 days of the treatment. The final $\mathrm{Pb}$ level was $500 \mu \mathrm{M} \mathrm{Pb} \mathrm{kg}{ }^{-1}$ dry soil. The $\mathrm{Pb}$ concentrations used in this study were chosen according to the $\mathrm{Pb}$ content of soil around the neighbouring lead mines. $12 \mathrm{~g}$ of slow-release fertilizer $(13 \% \mathrm{~N}, 10 \% \mathrm{P}$ and $14 \% \mathrm{~K}$ ) was added to each pot during the experiment. The treatments started on 15 May 2015, and the plants were harvested on 15 August 2015.

\section{Growth measurements}

At the end of the experiment, five cuttings from each sex and treatment were used for the biomass measurements. The cuttings were harvested and separated into leaves, stems and roots, and separately oven-dried at $70{ }^{\circ} \mathrm{C}$ for $48 \mathrm{~h}$ to constant weight and weighed. Total dry matter weight (TDW) equals the sum of leaf, stem and root dry matter weight. The biomass partition of leaves, stems and roots equals the ratio of dry matter weight of leaves, stems and roots to total dry matter weight, as expressed respectively as LDW/TDW, SDW/TDW and RDW/TDW.

\section{Gas exchange measurements}

The photosynthetic gas exchange measurements were conducted for the fourth fully expanded and intact leaf from five randomly chosen individuals from each treatment between 08:00 and 11:30 a.m. in July 2015 using a portable photosynthesis system (LI-6400; Li-Cor, Inc., Lincoln, NE, USA). The saturated photosynthetic photon flux density (PPFD) was determined by preliminary experiments. Prior to measurements, the samples were illuminated with saturated PPFD provided by the LED light source for 10-30 min to achieve a full photosynthetic induction. The net photosynthetic rate $\left(\mathrm{P}_{n}\right)$ and internal $\mathrm{CO}_{2}$ concentration of leaves $\left(\mathrm{C}_{\mathrm{i}}\right)$ were measured under following conditions: leaf temperature, $25{ }^{\circ} \mathrm{C}$; leaf-to-air vapour pressure deficit, $1.5 \pm 0.5 \mathrm{kPa}$; PPFD, $1500 \mu \mathrm{mol} \mathrm{m} \mathrm{m}^{-2} \mathrm{~s}^{-1}$; relative air humidity, 50\%; and ambient $\mathrm{CO}_{2}$ concentration, $400 \pm 5 \mu \mathrm{mol} \mathrm{mol}{ }^{-1}$. Once the apparent steady-state gas exchange was achieved, the steady-state data were recorded. The net photosynthetic responses to PPFD $\left(\mathrm{P}_{\mathrm{n}}\right.$-PPFD curve) were measured at $0,50,100,150,200,300,400,600,800,1000$, $1200,1500,1800 \mu \mathrm{mol} \mathrm{m}^{-2} \mathrm{~s}^{-1}$. Response curves were modeled by a non-rectangular hyperbola, as described by Prioul and Chartier (1977). The light-saturated photosynthetic rate $\left(\mathrm{P}_{\max }\right)$ and dark respiration rate $\left(\mathrm{R}_{\mathrm{D}}\right)$ were determined by fitting data to the model function, and the light compensation point (LCP) was derived by the linear regression of $P_{n}$ against PPFD. For the response curves of $P_{n}$ to $C_{i}\left(P_{n}-C_{i}\right.$ curve $)$, leaves were first exposed to their ambient $\mathrm{CO}_{2}$ concentration until steady-state gas exchange was observed. $\mathrm{CO}_{2}$ concentration was then reduced stepwise to $0 \mathrm{\mu mol} \mathrm{mol}^{-1}$ (400, $300,200,150,100,50,0)$ and increased stepwise to $1500 \mu \mathrm{mol} \mathrm{mol}^{-1}(400,600,800,1000,1200$ and $1500 \mu \mathrm{mol} \mathrm{mol}^{-1}$ ). The net photosynthetic rate versus $\mathrm{C}_{\mathrm{i}}$ curves over the range of $0-200 \mu \mathrm{mol} \mathrm{mol}{ }^{-1}$ was determined, and the regression of $\mathrm{CO}_{2}$ and $\mathrm{P}_{\mathrm{n}}$ was used to determine the $\mathrm{CO}_{2}$ compensation point $(\mathrm{CCP})$ and carboxylation efficiency (CE) (Olsson and Leverenz 1994). The maximum rate of electron transport driving regeneration of RuBP $\left(\mathrm{J}_{\max }\right)$ and maximum rate of RuBP carboxylation $\left(\mathrm{V}_{\mathrm{cmax}}\right)$ were determined according to Long and Bernacchi (2003).

Determination of pigment and total polyphenol contents of leaves

Pigments were determined for the same leaves, which were used for gas exchange measurements, employing the methods described by Lichtenthaler (1987). The leaf 
samples were extracted in $80 \%$ chilled acetone $(v / v)$. Absorbance of extracts was measured using spectrophotometry (Unicam UV-330; Unicam, Cambridge, UK) at 470,646 and $663 \mathrm{~nm}$. The total chlorophyll content was expressed as $\mathrm{mg} \mathrm{g}^{-1}$ on the basis of fresh weight (FW). The total chlorophyll content (chlorophyll $\mathrm{ab}_{\mathrm{ab}}$ ) was the sum of chlorophyll a and chlorophyll $b$. The total polyphenol content was determined by the Folin-Ciocalteu method using gallic acid as a standard (Julkunen-Tiitto 1985).

Determination of starch and soluble sugars in leaves and roots

About $50 \mathrm{mg}$ of dried fine powder from leaf and root samples in $4 \mathrm{ml} 80 \%(\mathrm{v} / \mathrm{v})$ ethanol was placed in a water bath at $80{ }^{\circ} \mathrm{C}$ for $30 \mathrm{~min}$, followed by centrifugation at $7000 \mathrm{~g}$ for $5 \mathrm{~min}$, after which the supernatant was transferred to a 10-ml centrifuge tube. Then, another $2 \mathrm{ml} 80 \%$ (v/v) ethanol was added to the sample, followed by centrifugation at $7000 \mathrm{~g}$ for $5 \mathrm{~min}$. This procedure was repeated again and the supernatants were pooled into the first $10-\mathrm{ml}$ centrifuge tube. The content of total soluble sugars was detected colorimetrically at $625 \mathrm{~nm}$ following the anthrone-sulfuric acid method. Residues left in the centrifuge tubes after sugar extraction were used to determine starch in glucose equivalents by using the anthrone reagent (Yemm and Willis 1954).

Determination of $\mathrm{N}$ and $\mathrm{P}$ contents in leaves and roots

Dried leaf and root samples $(0.2 \mathrm{~g})$ were used for $\mathrm{N}$ and $\mathrm{P}$ content measurements. $\mathrm{N}$ was determined by the semimicro Kjeldahl method (Mitchell 1998) and P was determined by induced plasma emission spectroscopy (Hötscher and Hay 1997). Photosynthetic N-use efficiency (PNUE) is expressed as $\mathrm{P}_{\max }$ divided by the foliar N content per area. Photosynthetic P-use efficiency (PPUE) is expressed as $\mathrm{P}_{\max }$ divided by the foliar $\mathrm{P}$ content per area.

Determination of $\mathrm{Pb}$ content

and phytoremediation-related index

Dried leaf, stem and root samples were ground to fine powder and passed through a 100-mesh screen. The determination of the $\mathrm{Pb}$ content was made by graphite furnace atomic absorption spectrometry (Analyst 300; Perkin
Elmer, Uberlingen, Germany). The bioconcentration factor $(\mathrm{BCF})$ is defined as the ratio of the metal concentration in the plant to the metal concentration in the soil (Zayed et al. 1998). The translocation factor (TF) is used to express the ability of plants to translate heavy metals from roots to harvestable aerial parts, and it is the ratio of the metal concentration in aboveground parts to the metal concentration in roots. The tolerance index (TI) is calculated as the mean dry matter weight of a plant grown under metal stress conditions divided by the mean weight of a control plant (Baker et al. 1994).

Transmission electron microscopy observations

Transmission electron microscopy (TEM) was performed on small sections (1-2 mm in length) of the fifth fully expanded leaves. Leaflets were fixed with $3 \%$ glutaraldehyde $(v / v)$ in $0.1 \mathrm{M}$ phosphate buffer (pH 7.2) for $6-8 \mathrm{~h}$ under $4{ }^{\circ} \mathrm{C}$, post-fixed in $1 \%$ osmium tetroxide for $1 \mathrm{~h}$ and immersed in $0.1 \mathrm{M}$ phosphate buffer $(\mathrm{pH} 7.2)$ for $1-2 \mathrm{~h}$. Then, the leaflets were dehydrated in a graded ethanol series $(50,60,70,80$, 90,95 and $100 \%$ ) and embedded in eponaraldite. Ultrathin sections $(80 \mathrm{~nm})$ were sliced, stained with uranyl acetate and lead citrate, and mounted on copper grids for viewing in H-600IV TEM (Hitachi, Tokyo, Japan).

Analysis of relative competitive intensity

The relative competitive intensity ( $\mathrm{RCI}$ ) of males and females when exposed to different competition and $\mathrm{Pb}$ treatments was determined, according to the following formula described by Grace (1995): $R C I=\left(B_{\text {inter }}-\right.$ $\left.B_{\text {intra }}\right) / B_{\text {intra }}$.

where $B_{\text {inter }}$ represents the leaf, stem, root and total dry matter weight of an individual from inter-sexual competition, and $\mathrm{B}_{\text {intra }}$ represents the leaf, stem, root and total dry matter weight of corresponding seedlings from intra-sexual competition.

Statistical analysis

All measurements were tested by a three-way ANOVA for the effects of sex, $\mathrm{Pb}$ and competition by using the SPSS 16.0 for windows statistical software package (SPSS, Inc., Chicago, IL, USA). Before ANOVAs, the 
data were checked for normality and the homogeneity of variances and log-transformed to correct deviations from these assumptions when needed. Differences between treatments were tested using Tukey's test at a significance level of $P<0.05$.

\section{Results}

Sex-specific competition induced responses to $\mathrm{Pb}$ in biomass accumulation and partition

Competition differently affected the biomass accumulation and partition of females and males exposed to $\mathrm{Pb}$ stress. The $\mathrm{Pb}$ treatment significantly decreased biomass accumulation in both sexes (Fig. 1a, c): in F/FM, F/FF,
$\mathrm{M} / \mathrm{FM}$ and $\mathrm{M} / \mathrm{MM}$, the total biomass decreased by $26.98 \%, 21.09 \%, 18.45 \%$ and $16.94 \%$, respectively, and the root biomass decreased by $35.75 \%, 30.88 \%$, $4.68 \%$ and $14.82 \%$, respectively, which indicates a greater $\mathrm{Pb}$-induced inhibition effect on females than males. Moreover, in the $\mathrm{Pb}$ treatment, females showed a lower root biomass and $\mathrm{R} / \mathrm{S}$ ratio than did males from intra- and inter-sexual competition. Concerning biomass partition, the LDW/TDW and SDW/TDW ratios of both sexes from different competition patterns showed no significant changes under a $\mathrm{Pb}$ treatment compared with controls. However, under $\mathrm{Pb}$ stress, the RDW/TDW and $\mathrm{R} / \mathrm{S}$ ratios of $\mathrm{F} / \mathrm{FM}$ and F/FF significantly decreased (Fig. 1b, d), while they increased in M/FM. The statistical analysis showed that the interaction of $\operatorname{sex} \times \mathrm{Pb}$ significantly

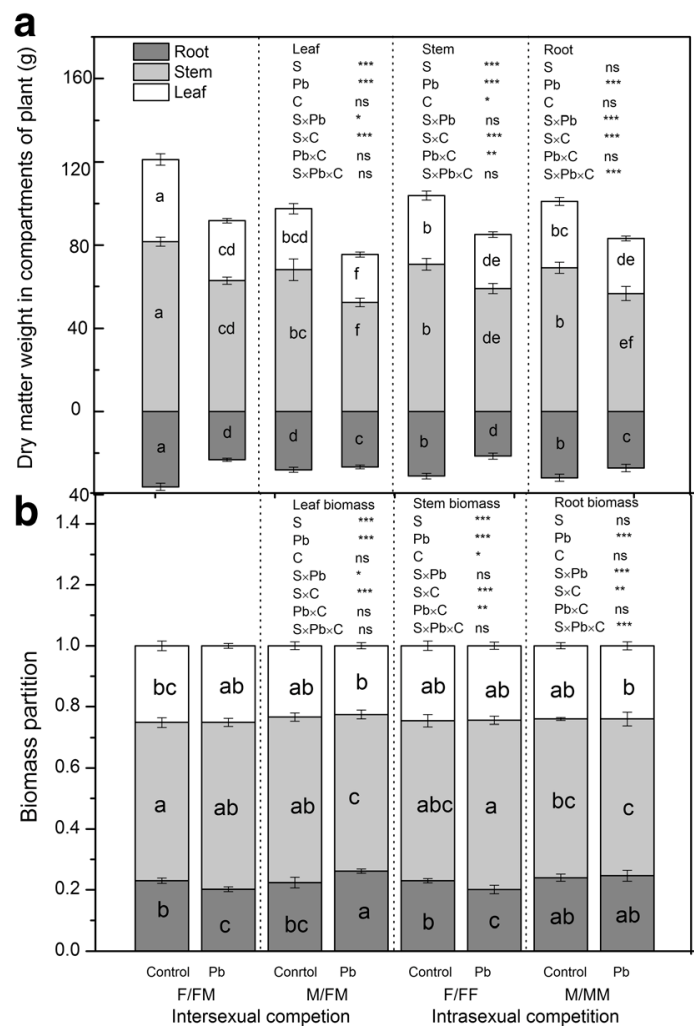

Fig. 1 Biomass accumulation and allocation traits of $P$. cathayana males and females exposed to $\mathrm{Pb}$ and sexual competition. (a) Dry matter weight in different parts of plants, (b) biomass partition, (c) total dry matter weight, (d) root/shoot ratio. Different letters above bars denote statistically significant differences between treatments at $\mathrm{P}<0.05$ level according to Tukey's test. Values are expressed as

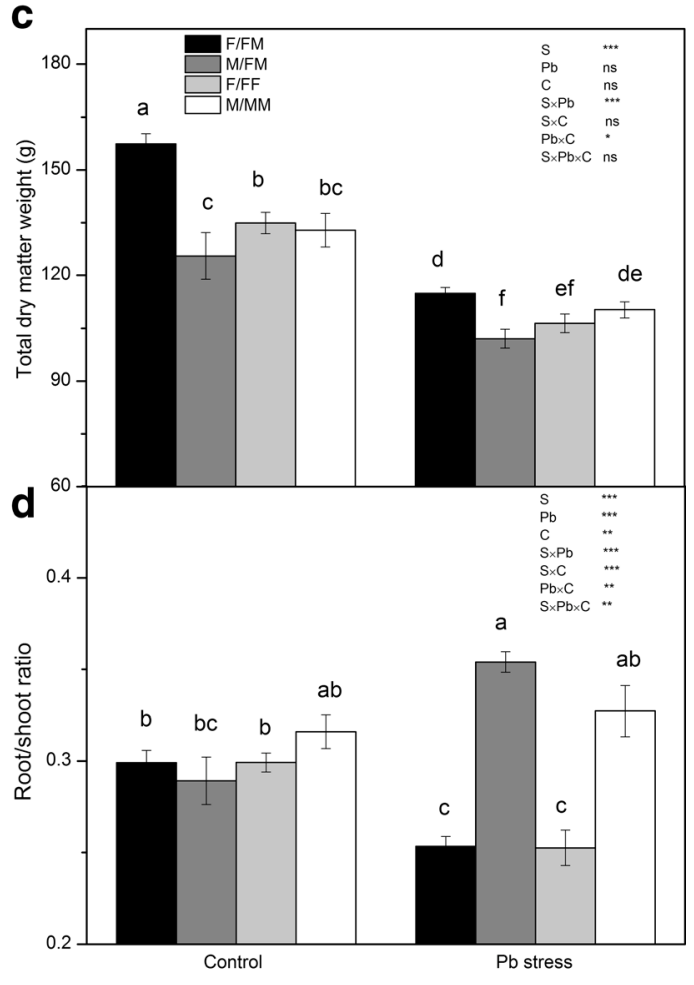

means \pm SE, $n=5 . * 0.01 \leq \mathrm{P}<0.05 ; * * 0.001 \leq \mathrm{P}<0.01$; $* * * \mathrm{P}<0.001$; ns, nonsignificant. Sex, sex effect; $\mathrm{Pb}, \mathrm{Pb}$ effect; $\mathrm{C}$, competition effect; sex $\times \mathrm{Pb}$, and $\operatorname{sex} \times \mathrm{C}$ the interaction effect of sex and $\mathrm{Pb}$, and sex and competition, respectively. $\mathrm{Pb} \times \mathrm{C}$, the interaction effect of $\mathrm{Pb}$ and competition; sex $\times \mathrm{Pb} \times \mathrm{C}$, the interaction effect of sex, $\mathrm{Pb}$ and competition 
affected leaf, root and total biomass, LDW/TDW, $\mathrm{RDW} / \mathrm{TDW}$ and $\mathrm{R} / \mathrm{S}$ ratios, and the sex $\times$ competition interaction significantly affected all growth parameters, except for the total biomass. The interaction of $\mathrm{Pb} \times$ competition significantly affected the stem and total biomass, SDW/TDW and $\mathrm{R} / \mathrm{S}$ ratio. The interaction of $\operatorname{sex} \times \mathrm{Pb} \times$ competition significantly affected the root biomass, RDW/ TDW and R/S ratio (Fig. 1).

Sex-specific competition induced responses to $\mathrm{Pb}$ in gas exchange

The sex-specific competition patterns induced different photosynthetic responses to $\mathrm{Pb}$ stress in the two sexes. As shown in Table 1, significant decreases in $\mathrm{P}_{\max }$ (range 36.7-57.4\%) were detected in both sexes under $\mathrm{Pb}$ stress, especially in females from intra-sexual competition $(57.4 \%)$ compared with the controls. Under inter-sexual competition, males showed lower $\mathrm{P}_{\max }$ than females under both control and $\mathrm{Pb}$ treatments. Among all competition patterns, F/FF showed the highest LCP and $R_{D}$ values, while $M / M M$ had the highest $P_{\max }$ and lowest LCP, CCP and $\mathrm{R}_{\mathrm{D}}$ in control conditions. The $\mathrm{Pb}$ treatment significantly inhibited $\mathrm{CE}$ and increased CCP of both sexes, except for F/FM. The $\mathrm{Pb}$ treatment significantly inhibited LCP, $\mathrm{V}_{\text {cmax }}$ and $\mathrm{J}_{\max }$ of both sexes. Among all competition patterns, females from intra-sexual competition showed the highest $R_{D}$ and lowest $C E$ values under $P b$ conditions. The statistical analysis showed that the interaction of sex $\times \mathrm{Pb}$ significantly affected $\mathrm{CE}, \mathrm{LCP}, \mathrm{R}_{\mathrm{D}}$, $\mathrm{V}_{\mathrm{cmax}}$ and $\mathrm{J}_{\max }$, and sex $\times$ competition significantly affected $\mathrm{P}_{\max }, \mathrm{CE}, \mathrm{CCP}, \mathrm{LCP}$ and $\mathrm{R}_{\mathrm{D}}$. The interaction of $\mathrm{Pb} \times$ competition significantly affected $\mathrm{P}_{\max }$, $\mathrm{CCP}, \mathrm{V}_{\mathrm{cmax}}$ and $\mathrm{J}_{\max }$, and the interaction of sex $\times$ $\mathrm{Pb} \times$ competition significantly affected $\mathrm{P}_{\max }, \mathrm{CE}$, CCP, LCP, $\mathrm{R}_{\mathrm{D}}, \mathrm{V}_{\mathrm{cmax}}$ and $\mathrm{J}_{\max }$.

In control conditions and under inter-sexual competition, females showed higher PNUE and PPUE than did males. No significant sex-related differences were observed in PNUE and PPUE under intrasexual competition. The $\mathrm{Pb}$ treatment significantly decreased PNUE and PPUE in both sexes, especially in $\mathrm{M} / \mathrm{FM}$ and $\mathrm{F} / \mathrm{FF}$ (Fig. 2a, b). The interaction of sex $\times$ competition significantly affected PNUE and PPUE, while the interaction of $\operatorname{sex} \times \mathrm{Pb} \times$ competition significantly affected PNUE.
Sex-specific competition induced responses to $\mathrm{Pb}$ in pigment and total polyphenol contents

In control conditions and under inter-sexual competition, females possessed a higher total chlorophyll $\mathrm{ab}_{\mathrm{ab}}$ content than did males. No significant difference in total chlorophyll $_{\mathrm{ab}}$ contents was observed in males and females under intra-sexual competition. The $\mathrm{Pb}$ treatment significantly decreased the total chlorophyll $\mathrm{ab}_{\mathrm{b}}$ content, especially in F/FF (Fig. 2c). The Pb stress significantly increased the total polyphenol content of both sexes, but males showed greater increases in all competition treatments (Fig. 2d). The interaction of sex $\times$ competition and sex $\times \mathrm{Pb}$ significantly affected total chlorophyll $\mathrm{ab}_{\mathrm{b}}$ and polyphenol contents.

Sex-specific competition induced responses to $\mathrm{Pb}$ in nutrient elements and carbohydrates

In control conditions and under inter-sexual competition, females showed higher $\mathrm{P}$ and $\mathrm{N}$ contents in leaves and roots than did males. The $\mathrm{Pb}$ treatment had no significant effect on the root and leaf $\mathrm{P}$ content of either sex under intra-sexual competition when compared with the controls. The combined treatment of inter-sexual competition and $\mathrm{Pb}$ stress caused no significant effect on the root $\mathrm{P}$ content, while it changed the leaf $\mathrm{P}$ content of both sexes, more in males than females. $\mathrm{Pb}$ stress increased the leaf $\mathrm{N}$ contents of $\mathrm{F} / \mathrm{FF}$ and $\mathrm{M} / \mathrm{FM}$ and decreased the $\operatorname{root} \mathrm{N}$ content of females, while it had no significant effect on males under intra- and inter-sexual competition (Fig. 3a, b). The interaction of sex $\times \mathrm{Pb}$ significantly affected leaf $\mathrm{P}$ and root $\mathrm{P}$ contents and the root $\mathrm{N}$ content. The interaction of sex $\times$ competition significantly affected the root $\mathrm{N}$ content, and the interaction of sex $\times \mathrm{Pb} \times$ competition significantly affected the root $\mathrm{P}$ and leaf $\mathrm{N}$ content.

In control conditions, F/FM showed the lowest leaf starch content among all competition treatments. The $\mathrm{Pb}$ stress increased leaf starch contents of both sexes, except for $\mathrm{M} / \mathrm{MM}$, and increased also root starch contents of both sexes, except for F/FF. Moreover, F/FF had the highest leaf starch content, while $\mathrm{M} / \mathrm{MM}$ had the highest root starch content among all competition patterns. The $\mathrm{Pb}$ treatment significantly increased the soluble sugar contents of leaves and roots of both sexes, except for F/ $\mathrm{FF}$ and $\mathrm{M} / \mathrm{MM}$, respectively. In addition, M/FM possessed higher levels of leaf and root soluble sugars than 


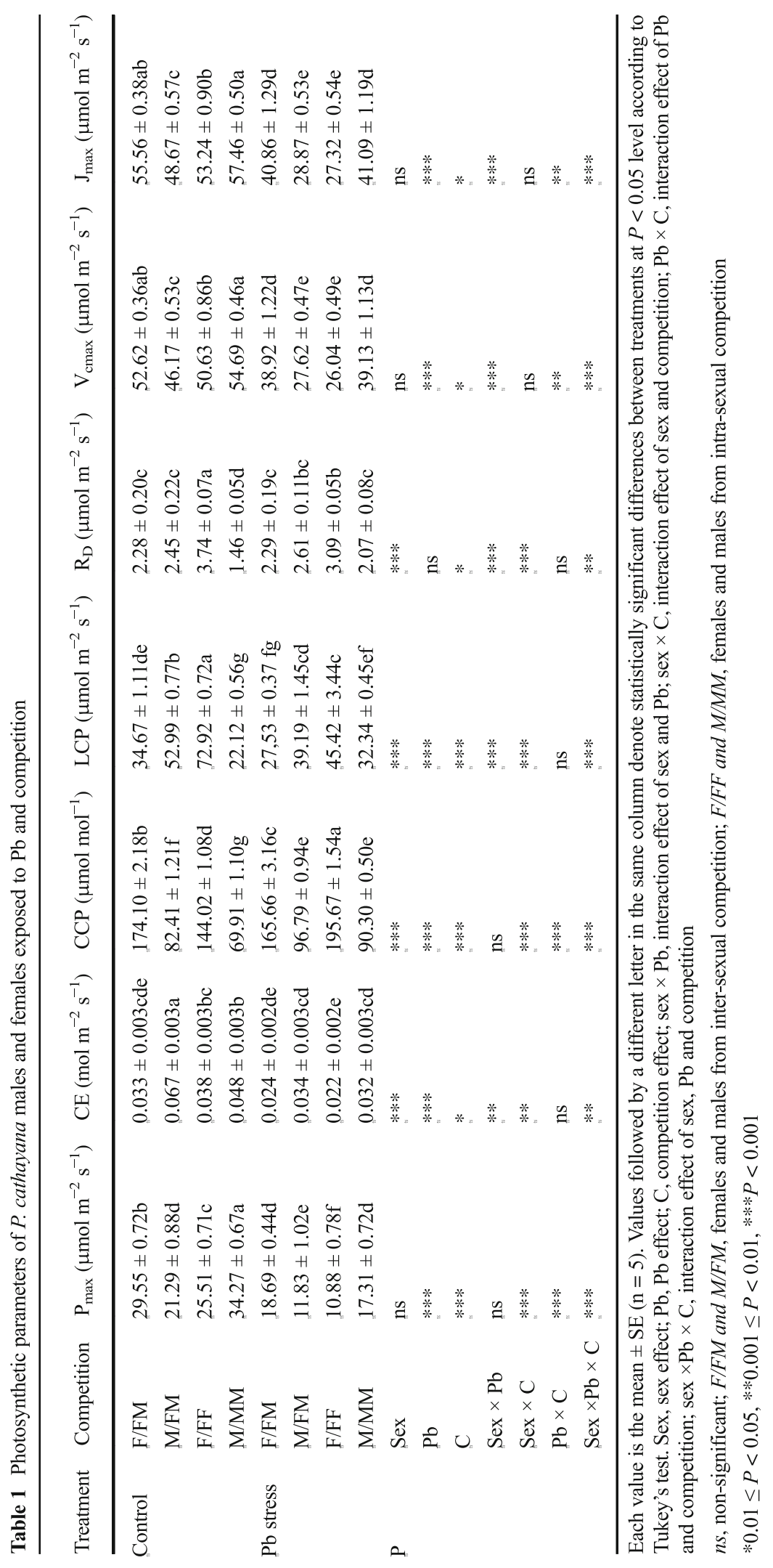



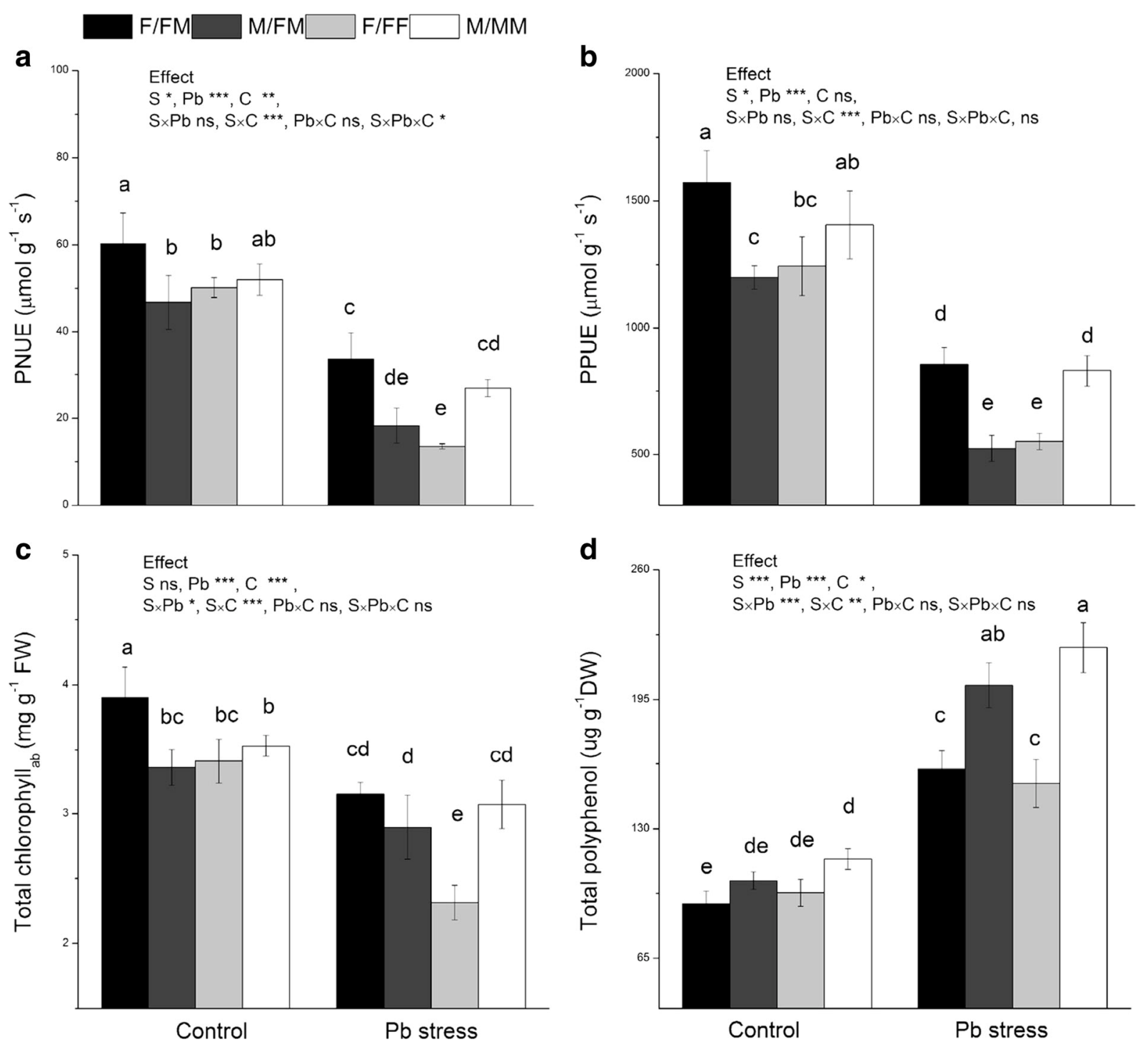

Fig. 2 Leaf-related traits of $P$. cathayana males and females exposed to $\mathrm{Pb}$ and sexual competition. (a) Photosynthetic nitrogen use efficiency (PNUE), (b) photosynthetic phosphorus use

F/FM. The interaction of sex $\times \mathrm{Pb}$, sex $\times$ competition and sex $\times \mathrm{Pb} \times$ competition significantly affected leaf starch and root soluble sugar contents. Additionally, the interaction of sex $\times \mathrm{Pb}$, sex $\times$ competition and $\mathrm{Pb} \times$ competition significantly affected root starch and leaf soluble sugar contents.

Sex-specific competition induced responses to $\mathrm{Pb}$ uptake and phytoremediation parameters

Competition patterns significantly affected the $\mathrm{Pb}$ uptake and phytoremediation parameters (Table 2). Under

efficiency (PPUE), (c) total chlorophyll ${ }_{\mathrm{ab}}$ content, (d) total polyphenol content. Data presentation and statistical significances as in Fig. 1

$\mathrm{Pb}$ treatment and inter-sexual competition, females showed higher levels of leaf and stem $\mathrm{Pb}$ and TF but lower root and total $\mathrm{Pb}$ contents when compared to males. No significant differences were observed between the sexes in root and total $\mathrm{Pb}$ contents under intra-sexual competition. In addition, females from intra- and inter-sexual competition showed higher leaf and stem $\mathrm{Pb}$ contents, $\mathrm{BCF}_{\text {leaf }}$ and $\mathrm{BCF}_{\text {stem }}$ when compared to males, while $\mathrm{M} / \mathrm{FM}$ showed the highest root $\mathrm{Pb}$ content, $\mathrm{BCF}_{\text {root }}, \mathrm{BCF}_{\text {total }}$ and $\mathrm{TI}_{\text {root }}$ among $\mathrm{Pb}$ treatments. However, males and females had no significant differences in $\mathrm{TI}_{\text {leaf }}$ and $\mathrm{TI}_{\text {stem }}$. 

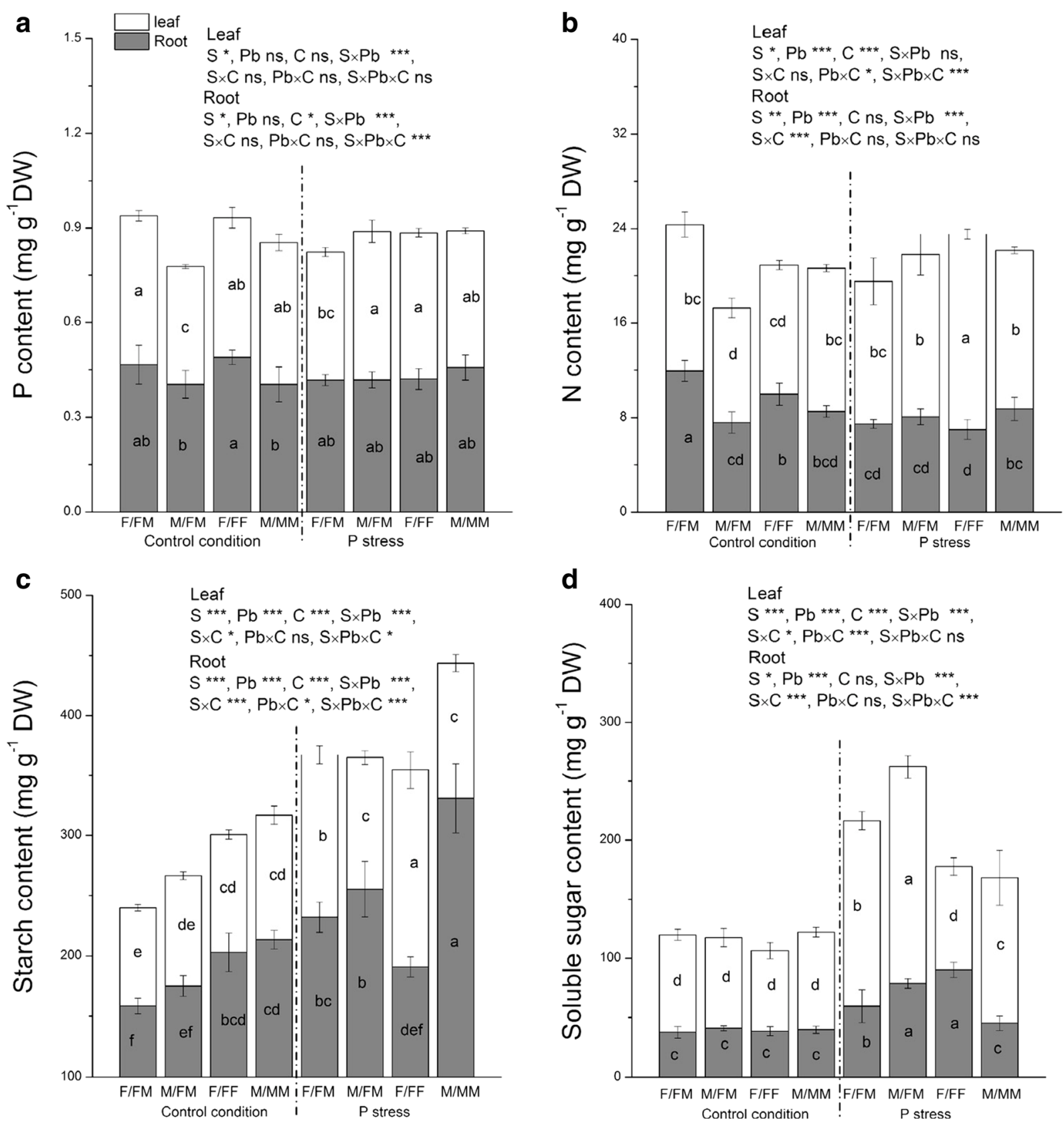

Fig. 3 Nutrient elements and carbohydrates in leaves and roots of $P$. cathayana males and females exposed to $\mathrm{Pb}$ and sexual competition. (a) $\mathrm{P}$ content, (b) N content, (c) starch content and (d) soluble sugar content. Data presentation and statistical significances as in Fig. 1

Sex-specific competition induced responses to $\mathrm{Pb}$ in cellular ultrastructure

Sex-related differences in cellular ultrastructure are presented in Fig. 4. In control conditions, both females and males had smooth, clean and continuous cell membranes, and a granular cytoplasm densely filled with numerous organelles. The chloroplasts exhibited a lenticular shape, and mitochondria had a typical structure and clear cristae. The combination of $\mathrm{Pb}$ and competition had severe effects on the ultrastructure of leaf cells in both sexes, such as abnormal cell walls, and seriously distorted chloroplasts with large starch granules and disintegrated 
Table $2 \mathrm{~Pb}$ content, bioconcentration factor $(\mathrm{BCF})$, tolerance index (TI) and translation factor (TF) of $P$. cathayana females and males exposed to $\mathrm{Pb}$ and competition

$\mathrm{Pb}$ treatment

\begin{tabular}{|c|c|c|c|c|}
\hline \multirow[b]{2}{*}{ Parameter } & \multicolumn{2}{|c|}{ Inter-sexual competition } & \multicolumn{2}{|c|}{ Intra-sexual competition } \\
\hline & $\mathrm{F} / \mathrm{FM}$ & $\mathrm{M} / \mathrm{FM}$ & $\mathrm{F} / \mathrm{FF}$ & $\mathrm{M} / \mathrm{MM}$ \\
\hline Leaf $\mathrm{Pb}\left(\mathrm{mg} \mathrm{g}^{-1} \mathrm{DW}\right)$ & $\begin{array}{l}16.73 \\
\pm 1.20 \mathrm{a}\end{array}$ & $\begin{array}{l}12.31 \\
\quad \pm 1.57 \mathrm{bc}\end{array}$ & $\begin{array}{l}14.54 \\
\quad \pm 1.35 \mathrm{ab}\end{array}$ & $11.56 \pm 0.69 c$ \\
\hline Stem $\mathrm{Pb}\left(\mathrm{mg} \mathrm{g}^{-1} \mathrm{DW}\right)$ & $\begin{array}{l}12.28 \\
\pm 0.89 \mathrm{a}\end{array}$ & $9.58 \pm 1.26 \mathrm{~b}$ & $13.71 \pm 0.79 \mathrm{a}$ & $10.51 \pm 0.62 b$ \\
\hline Root $\mathrm{Pb}\left(\mathrm{mg} \mathrm{g}^{-1} \mathrm{DW}\right)$ & $\begin{array}{l}24.47 \\
\quad \pm 4.01 \mathrm{c}\end{array}$ & $76.92 \pm 7.79 \mathrm{a}$ & $53.53 \pm 3.59 b$ & $\begin{array}{l}55.75 \\
\quad \pm 10.13 \mathrm{~b}\end{array}$ \\
\hline${ }_{\text {Total }} \mathrm{Pb}\left(\mathrm{mg} \mathrm{g}^{-1} \mathrm{DW}\right)$ & $\begin{array}{l}15.86 \\
\quad \pm 0.32 \mathrm{c}\end{array}$ & $27.76 \pm 1.05 \mathrm{a}$ & $21.95 \pm 0.48 b$ & $21.94 \pm 1.31 \mathrm{~b}$ \\
\hline $\mathrm{BCF}_{\text {leaf }}$ & $0.16 \pm 0.01 \mathrm{a}$ & $0.12 \pm 0.02 b c$ & $0.14 \pm 0.01 \mathrm{a}$ & $0.11 \pm 0.01 \mathrm{c}$ \\
\hline $\mathrm{BCF}_{\text {stem }}$ & $0.12 \pm 0.01 \mathrm{a}$ & $0.09 \pm 0.01 \mathrm{~b}$ & $0.13 \pm 0.01 \mathrm{a}$ & $0.10 \pm 0.01 b$ \\
\hline $\mathrm{BCF}_{\text {root }}$ & $0.24 \pm 0.04 \mathrm{c}$ & $0.74 \pm 0.08 \mathrm{a}$ & $0.52 \pm 0.03 b$ & $0.54 \pm 0.10 \mathrm{~b}$ \\
\hline $\mathrm{BCF}_{\text {total }}$ & $\begin{array}{l}0.15 \\
\quad \pm 0.000 \mathrm{c}\end{array}$ & $0.27 \pm 0.02 \mathrm{a}$ & $0.21 \pm 0.01 \mathrm{~b}$ & $0.21 \pm 0.03 b$ \\
\hline $\mathrm{TI}_{\text {leaf }}$ & $0.16 \pm 0.01 \mathrm{a}$ & $0.12 \pm 0.02 \mathrm{a}$ & $0.14 \pm 0.01 \mathrm{a}$ & $0.11 \pm 0.01 \mathrm{a}$ \\
\hline $\mathrm{TI}_{\text {stem }}$ & $0.12 \pm 0.01 \mathrm{a}$ & $0.09 \pm 0.01 \mathrm{a}$ & $0.13 \pm 0.01 \mathrm{a}$ & $0.10 \pm 0.01 \mathrm{a}$ \\
\hline "TI $\mathrm{I}_{\text {root }}$ & $0.64 \pm 0.05 \mathrm{c}$ & $0.95 \pm 0.05 \mathrm{a}$ & $0.69 \pm 0.06 \mathrm{c}$ & $0.85 \pm 0.05 \mathrm{~b}$ \\
\hline "TI $\mathrm{I}_{\text {total }}$ & $0.15 \pm 0.01 \mathrm{~b}$ & $0.27 \pm 0.02 \mathrm{a}$ & $0.21 \pm 0.01 \mathrm{ab}$ & $0.21 \pm 0.03 \mathrm{a}$ \\
\hline $\mathrm{TF}$ & $1.22 \pm 0.25 \mathrm{a}$ & $0.29 \pm 0.02 \mathrm{c}$ & $0.53 \pm 0.05 b$ & $0.41 \pm 0.08 \mathrm{bc}$ \\
\hline
\end{tabular}

Each value is the mean $\pm \mathrm{SE}(\mathrm{n}=5)$. Values followed by a different letter in the same row denote statistically significant differences between treatments at $\mathrm{P}<0.05$ level according to Tukey's test

mitochondrial cristae (Fig. 4c-f). Females from intra-sexual competition and males from intersexual competition possessed fewer normal and more deformed chloroplasts, incorrectly arranged inner membranes, vacuolization and decreased organellar density in the cytoplasm compared with other competition patterns when exposed to $\mathrm{Pb}$ stress (Fig. 4d, e).

\section{Analysis of competition index}

As shown in Fig. 5, females from inter-sexual competition showed positive values, while neighboring males had negative values of $\mathrm{RCI}_{\text {leaf }}, \mathrm{RCI}_{\text {stem }}, \mathrm{RCI}_{\text {root }}$ and $\mathrm{RCI}_{\text {total }}$ under control and $\mathrm{Pb}$ treatments. This means that females grow better than do males under intersexual competition. $\mathrm{Pb}$ stress did not change the competitive trend, but it significantly altered the degree of leaf, root and total competitive pressure and intensity.

\section{Discussion}

Competition differently affects eco-physiological parameters and phytoremediation in $P$. cathayana males and females

Previous studies have reported that there are sex-related differences in $P$. cathayana in responses to heavy metal treatments, and males possess better tolerance when compared to females (Chen et al. 2011; Han et al. 2013). Our results indicated that sexual competition significantly affects biomass accumulation and partition, photosynthetic capacity, carbohydrates, $\mathrm{N}$ and $\mathrm{P}$ contents, and ultrastructure in $P$. cathayana males and females under $\mathrm{Pb}$ stress. Males were better adapted, visible as higher root biomass, RDW/TDW, R/S ratio, $\mathrm{P}_{\max }, \mathrm{CE}, \mathrm{V}_{\mathrm{cmax}}, \mathrm{J}_{\max }$, PNUE, PPUE, and leaf total chlorophyll $_{\mathrm{ab}}$ and polyphenol contents, and as lower CCP, LCP and leaf starch content, and less damaged ultrastructure when compared to females under intra- 
Fig. 4 Transmission electron microscopy observations of mesophyll cells in P. cathayana males and females exposed to $\mathrm{Pb}$ and sexual competition. (a) Mesophyll cells of control females; (b) mesophyll cells of control males; (c) mesophyll cells of females exposed to $\mathrm{Pb}$ and inter-sexual competition; (d) mesophyll cells of males exposed to $\mathrm{Pb}$ and inter-sexual competition; (e) mesophyll cells of females exposed to $\mathrm{Pb}$ and intra-sexual competition; (f) mesophyll cells of males exposed to $\mathrm{Pb}$ and intrasexual competition. The bars shown are $1 \mu \mathrm{m}$. C, chloroplast; $\mathrm{CW}$, cell wall; $\mathrm{S}$, starch granule; $\mathrm{G}$, granum; N, nucleus; $\mathrm{M}$, mitochondrion; $\mathrm{N}_{\mathrm{C}}$, nucleolus; $\mathrm{V}$, vacuole
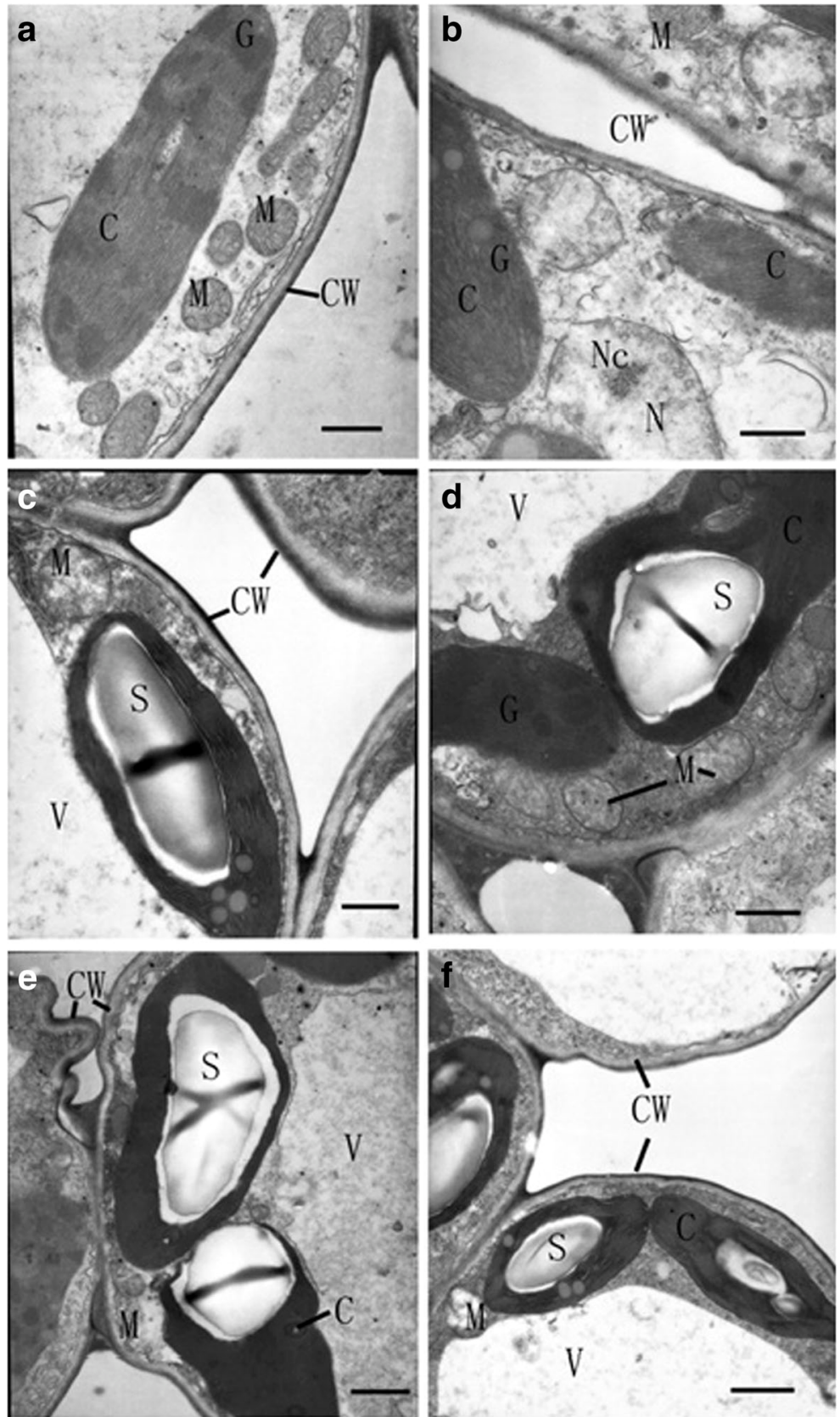

sexual competition and $\mathrm{Pb}$ stress. In control conditions, females from inter-sexual competition grew better than males, while the $\mathrm{Pb}$ treatment significantly decreased biomass accumulation, more in females than in males. Moreover, males caused a positive effect on females under inter-sexual competition by accumulating more $\mathrm{Pb}$ in roots. Males also had higher BCF and a lower competitive ability, as shown as lower biomass accumulation, PPNE, PNUE, $\mathrm{P}_{\max }, \mathrm{V}_{\mathrm{cmax}}$ and $\mathrm{J}_{\max }$, all indicating lower resource capture for light and nutrients.

Plant growth is linked closely with intrinsic physiological processes, including photosynthesis, nutrient uptake and metabolism. In our study, the inhibited $\mathrm{V}_{\mathrm{cmax}}$ and $\mathrm{J}_{\max }$ values under $\mathrm{Pb}$ stress supported the view that the limitation of Rubisco carboxylation and RuBP regeneration caused the decreases in the photosynthetic rate and carbon 
a
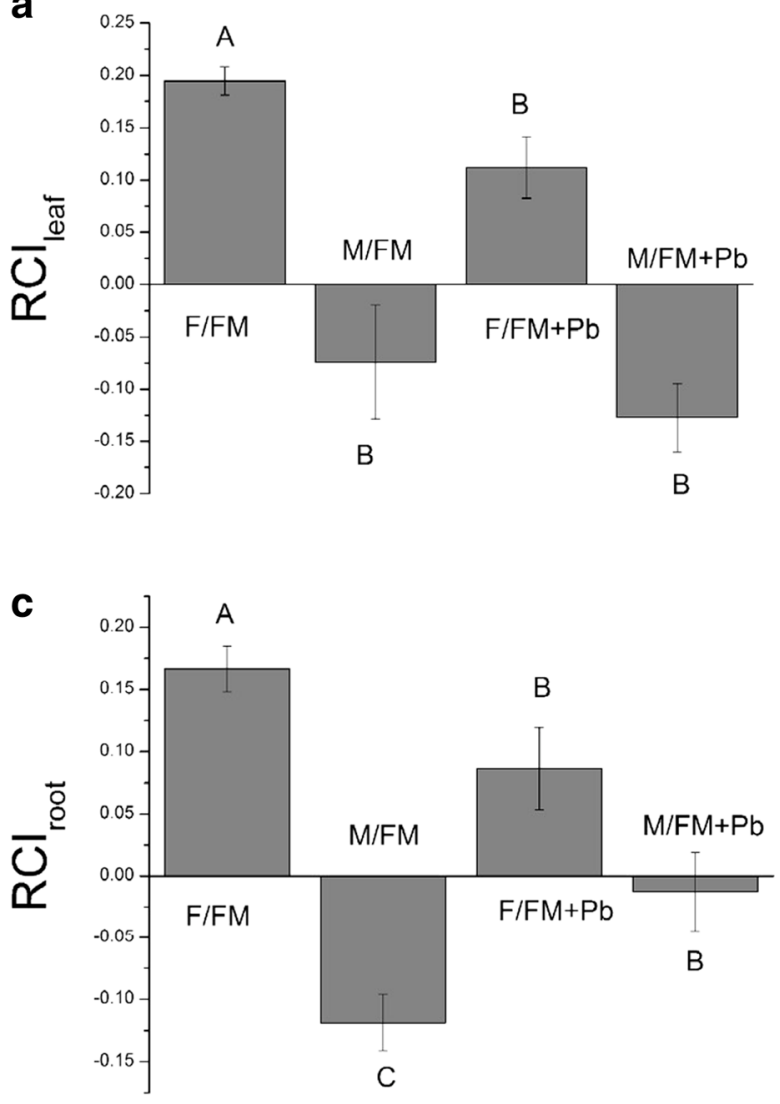

b

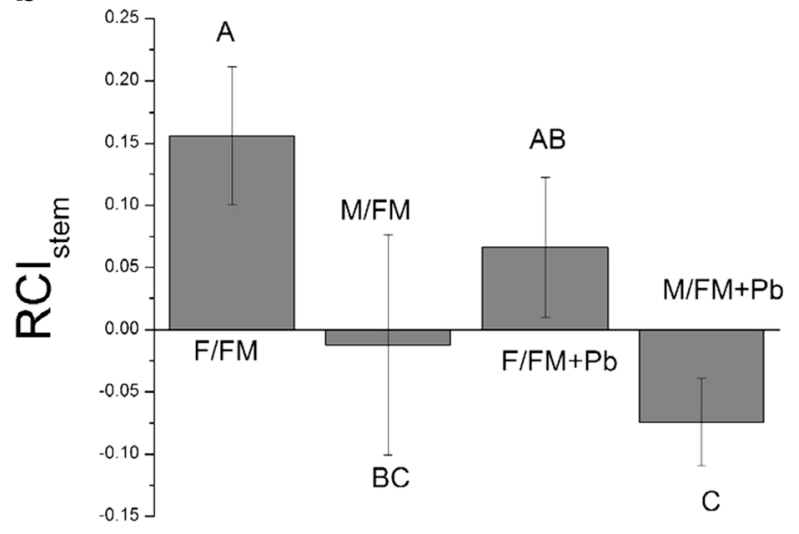

d

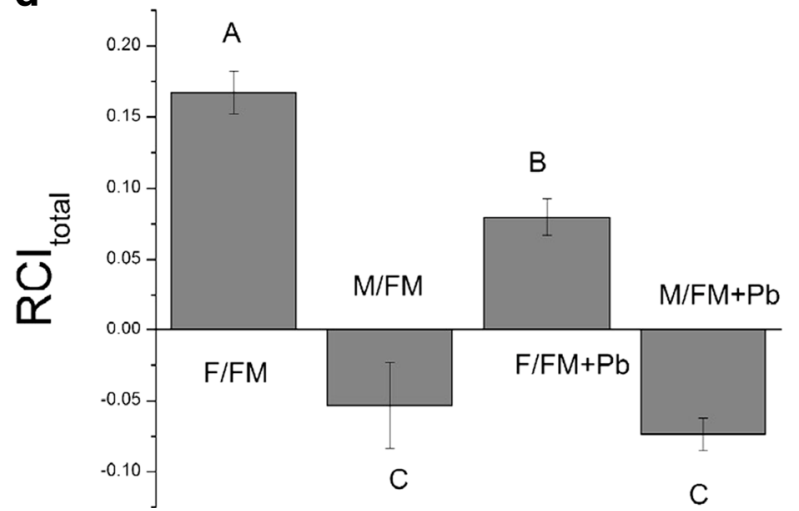

Fig. $5 \mathrm{RCI}$ analysis of $P$. cathayana males and females exposed to $\mathrm{Pb}$ and sexual competition. Different letters above bars denote statistically significant differences between treatments at $\mathrm{P}<0.05$ level according to Tukey's test. Values are expressed as means $\pm S E, n=5$

assimilation (Long and Bernacchi 2003). Males exhibited a greater plasticity in the photosynthetic capacity compared with females under $\mathrm{Pb}$ stress combined with intrasexual competition, which may induce more starch and biomass accumulation in male roots. The high $\mathrm{P}_{\max }$ and lower $R_{D}$ values detected in males indicate a greater photosynthetic return for carbon used for dark respiration, while higher $C E, V_{c \max }$ and $J_{\max }$ in males indicate less reduced rubisco activity and high carbon-use efficiency compared with females under $\mathrm{Pb}$ stress and intra-sexual competition. These results are similar to the responses previously discovered in single-plant experiments (Han et al. 2013). However, under inter-sexual competition, males showed lower $P_{\max }, V_{c \max }, J_{\max }, C C P$, less leaf, stem and total biomass than did females under control and $\mathrm{Pb}$ stress conditions, which indicates that competition patterns significantly affect the photosynthetic function and growth traits in both sexes. $\mathrm{Pb}$ had severe effects on the ultrastructure of leaf cells in both sexes, as shown as a serious distortion of chloroplasts with larger starch granules and disintegrated mitochondrial cristae, which supports the observation reported in previous studies on poplars (Chen et al. 2011; Han et al. 2013). Compared with other competition patterns combined with $\mathrm{Pb}$ stress, females from intra-sexual competition and males from inter-sexual competition had more deformed chloroplasts. Simultaneously, females from intra-sexual competition showed the lowest chlorophyll $l_{\mathrm{ab}}$ content among all competition patterns under $\mathrm{Pb}$ treatment. These different responses in photosynthetic-related traits further explained the divergence in biomass accumulation in females and males under $\mathrm{Pb}$ stress combined with competition.

Plants' competitive abilities and interactions vary along with the availability of $\mathrm{N}$ or $\mathrm{P}$ (Trinder et al. 2012; Ahmad-Ramli et al. 2013; Mayor et al. 2014). The growth-rate hypothesis (GRH) states that organisms require relatively more investment in phosphorus-rich ribosomes and rRNA to support the rapid protein 
synthesis and thus exhibit lower tissue N: P and C: P ratios (Sterner and Elser 2002). In our study, males and females showed significant differences in $\mathrm{N}$ and $\mathrm{P}$ concentrations and allocation to roots and leaves, while no significant changes in N: $\mathrm{P}$ ratios were observed, which did not totally support GSH. Competition changes the availability and transformation of essential nutrients that may affect plants' responses to abiotic stresses and also the nutrient cycle in the local ecosystem. Our results indicated that females have a greater leaf $\mathrm{P}$ content and higher PNUE and PPUE than do males in control conditions and under inter-sexual competition, which supports greater biomass accumulation in females. The $\mathrm{Pb}$ treatment significantly decreased the root $\mathrm{N}$ content of females but not that of males under intra-and intersexual competition. In addition, $\mathrm{Pb}$ stress significantly decreased PNUE and PPUE of both sexes. Moreover, $\mathrm{M} / \mathrm{FM}$ and F/FF had lower PPNU under Pb stress, which may cause their lower biomass accumulation among competition patterns. In all, these results indicated that the type of neighbors affects the nutrient absorption and use efficiency, but males and females display different responses to $\mathrm{Pb}$ stress.

In addition, non-structural carbohydrates (NSC) play a key role in serving as signaling molecules, providing basic $\mathrm{C}$ energy to growth and respiration, and maintaining osmoregulation (Secchi and Zwieniecki 2011). It has been found that negative and positive competition patterns have different impacts on species' NSC and modulate the accumulation of starch and soluble sugars (Liu et al. 2004; Guo et al. 2016). In our study, Pb stress was found to significantly alter starch and soluble sugar contents of leaves and roots. The highest starch contents of leaves and roots among all competition patterns were observed in females and males under intra-sexual competition. This may result in changes in the efficiency of photosynthesis in leaves, and in the regulation of carbohydrate storage and nutrient uptake in roots.

According to the carbon-nutrient balance hypothesis, the amounts of nonstructural carbohydrates and C-based secondary metabolites, such as polyphenols, are determined by environmental conditions and plant growth strategy; stressful conditions are expected to enhance $\mathrm{C}$ investments in storage and defense (Paul-Victor et al. 2010; Millard and Way 2011). Heavy metal toxicity is well known to be related to the polyphenols in plants (Llugany et al. 2013). Polyphenols, such as tannins and phenolics, act as organic ligands for metal chelation to decrease the toxicity of heavy metals (He et al. 2013). A previous study has indicated that competition influences the content of phenolic glycosides, consequently possibly affecting plant tolerance to heavy metal stress (Donaldson et al. 2006). As shown in Fig 2d, males possessed a higher leaf polyphenol content when compared to females under $\mathrm{Pb}$ stress, which may help males to alleviate the suppression of photosynthesis caused by $\mathrm{Pb}$ stress. Our results showed that sex-specific competition has a significant effect on the phytoremediation traits. Under $\mathrm{Pb}$ stress, females from intra- and intersexual competition showed higher leaf and stem $\mathrm{Pb}$ contents, and $\mathrm{BCF}_{\text {leaf }}$ and $\mathrm{BCF}_{\text {stem }}$ when compared to males, while $\mathrm{M} / \mathrm{FM}$ had the highest root $\mathrm{Pb}$ content, $\mathrm{BCF}_{\text {root }}, \mathrm{BCF}_{\text {total }}$ and $\mathrm{TI}_{\text {root }}$, which, thus, indicates different $\mathrm{Pb}$ allocation and tolerance strategies in the aboveground and belowground parts of $P$. cathayana.

Sex-specific competition intensities altered by $\mathrm{Pb}$ stress

Positive and negative interactions among plant species vary along environmental factors and gradients (Maestre et al. 2009). In addition, plants' responses may depend on the interacting neighbors. In the present study, females from inter-sexual competition showed intensive competition pressure on males in control conditions, while $\mathrm{Pb}$ stress changed the intensity and pattern of inter-sexual competition (Fig. 5). The Pb stress and intra-sexual competition showed greater negative effects on the growth and physiological parameters of females than on those of males. Individuals of the same sex usually have similar demands for specific environmental resources, and this will induce a greater competition pressure under an environmental stress. It has been reported that species can distinguish con- and hetero-specific individuals (Kegge and Pierik 2010), and this may affect plant interactions (Miller et al. 2007; Duan et al. 2014). Therefore, we assumed that the two sexes of dioecious species may distinguish the same or opposite sex in the neighborhood, consequently altering their root distribution and investment for resource capture, possibly leading to changes in the intensity and pattern of competition.

Neighboring trees compete for available light aboveground and for water and nutrients belowground, which may influence the intensity of nutrient cycling rates and ecosystem functioning (Deyn and van der Putten 2005; Santiago et al. 2012). In our study, Pb stress and the presence of neighbors changed aboveground and belowground competitive interactions of the two sexes. A positive $\mathrm{RCI}$ value in females under control and $\mathrm{Pb}$ 
stress conditions stands for a better growth with a neighbor of the opposite sex than with a neighbor of the same sex. Males showed negative CRI in the leaf, stem, root and total biomass under inter-sexual competition and control conditions. However, $\mathrm{Pb}$ stress significantly decreased competitive intensities of both sexes (Fig. 5).

The stress gradient hypothesis indicates that facilitation is most common in severe environments (Callaway and Walker 1997). These amelioration or deterioration effects of interacting plants in local microhabitats vary along with the abiotic stress. In our study, males and females showed different responses when competing with individuals of the same or opposite sex. Females exerted a negative effect on the growth performance of male seedlings under control conditions, mainly due to the high growth rate of females. Under the $\mathrm{Pb}$ treatment, females benefited from the amelioration effect by males in inter-sexual competition, because neighboring males absorbed more $\mathrm{Pb}$ and possessed a lower resource use and biomass accumulation. The intra-sexual competition had a greater negative influence on females than on males under $\mathrm{Pb}$ stress. Males and females adjusted the soil resource levels and the outcome of competitive interactions, which might be relative to niche modifications (McKane et al. 2002). It has been found that sexual competition patterns affect the root: shoot ratio and function for capturing resources (Rogers and Eppley 2012). Therefore, differences between males and females in the sensitivity to neighboring plants are considered to be an important factor driving sex-specific growth patterns, physiological processes and the intensity of competition. Our results suggest that sexual competition should be considered when developing strategies for forestation and restoration of contaminated land. In $\mathrm{Pb}$ contaminated soils, a mixture of $P$. cathyana males and females should be in proper ratios and space to decrease the inter-sexual competitive pressure on males, and more males could be utilized for phytoremediation due to their better tolerance and lower intra-sexual competition pressure.

\section{Conclusions}

Our results indicated that sexual competition patterns alter the responses and phytoremediation of males and females under $\mathrm{Pb}$ stress. The sensitivity of males and females to $\mathrm{Pb}$ stress depends on the sex of their competitor. Compared with the control conditions, $\mathrm{Pb}$ stress changed the intensity of competition in males and females. The dynamics of the competitive index, photosynthetic parameters, PNUE, PPUE, the contents of carbohydrates, $\mathrm{N}, \mathrm{P}$, chlorophyll $\mathrm{ab}_{\mathrm{ab}}$ and polyphenols, and alterations in ultrastructure and phytoremediation-related parameters, including $\mathrm{BCF}$, TI and TF, indicated that sexual competition patterns significantly affect the responses and adaptation of $P$. cathayana seedlings to $\mathrm{Pb}$ stress. These different responses of seedlings would have longterm effects on the growth, reproduction investment and competitiveness of adult female and male plants. We suggest that sexual competition may partially explain the growth differences and spatial segregation of sexes in heavy metal contaminated regions. In the process of forestation and restoration of contaminated soil, more attention should be paid in the future on the effects of inter- and intra-sexual competition on dioecious species.

Acknowledgements This work was supported by the China Postdoctoral Science Foundation (2015M570797), the Talent Program of the Mianyang Normal University (QD2015A005) and the Talent Program of the Hangzhou Normal University (2016QDL020).

Author's contribution Juan Chen had the main responsibility for data collection, analysis and writing, Qingquan Han and Baoli Duan had a significant contribution to data collection and analysis, Helena Korpelainen had a significant contribution to the interpretation of data and manuscript preparation, and Chunyang $\mathrm{Li}$ (the corresponding author) had the overall responsibility for experimental design and project management.

\section{Compliance with ethical standards}

Conflict of interest The authors declare that they have no conflicts of interest.

\section{References}

Ahmad-Ramli MF, Cornulier T, Johnson D (2013) Partitioning of soil phosphorus regulates competition between Vaccinium vitisidaea and Deschampsia cespitosa. Ecol Evol 3:4243-4252

Baker AJM, McGrath SP, Sideli CMD, Reeves RD (1994) The possibility of in-situ heavy metal decontamination of polluted soils using crops of metal-accumulating plants - a feasibility study. Resour Conserv Recycl 11:41-49

Bertness MD, Callaway R (1994) Positive interactions in communities. Trends Ecol Evol 9:191-193 
Bloor JMG, Leadley PW, Barthes L (2008) Responses of Fraxinus excelsior seedlings to grass-induced above- and belowground competition. Plant Ecol 194:293-304

Callaway RM, Walker L (1997) Competition and facilitation: a synthetic approach to interactions in a plant community. Ecology 78:1958-1965

Chen LH, Zhang S, Zhao HX, Korpelainen H, Li CY (2010) Sexrelated adaptive responses to interaction of drought and salinity in Populus yunnanensis. Plant Cell Environ 33:1767-1778

Chen LH, Han Y, Jiang H, Korpelainen H, Li CY (2011) Nitrogen nutrient status induces sexual differences in responses to cadmium in Populus yunnanensis. J Exp Bot 62:5037-5050

Dawson TE, Ehleringer JR (1993) Gender-specific physiology, carbon isotope discrimination, and habitat distribution in boxelder, Acer negundo. Ecology 74:798-815

Deyn GB, Van der Putten WH (2005) Linking aboveground and belowground diversity. Trends Ecol Evol 20:625-633

Donaldson JR, Kruger EL, Lindroth RL (2006) Competition and resource-mediated tradeoffs between growth and defensive chemistry in trembling aspen (Populus tremuloides). New Phytol 169:561-570

Duan BL, Dong TF, Zhang XL, Zhang YB, Chen J (2014) Ecophysiological responses of two dominant subalpine tree species Betula albosinensis and Abies faxoniana to intra- and interspecific competition under elevated temperature. For Ecol Manag 323:20-27

Dudley LS (2006) Ecological correlates of secondary dimorphism in Salix glauca (Salicaceae). Am J Bot 93:1775-1783

Dybzinski R, Tilman D (2007) Resource use patterns predict longterm outcomes of plant competition for nutrients and light. Am Nat 170:305-318

Eppley SM (2006) Females make tough neighbours: sex-specific competitive effects in seedlings of a dioecious grass. Oecologia 46:549-554

Ermakov VV, Petrunina NS, Tyutikov SF, Danilova VN, Khushvakhtova SD, Degtyarev AP, Krechetova EV (2015) Concentrating metals by plants of the genus Salix and their importance for identification of $\mathrm{Cd}$ anomalies. Geochem Int 53:951-963

Fargione J, Brown CS, Tilman D (2003) Community assembly and invasion: an experimental test of neutral versus niche processes. Proc Natl Acad Sci U S A 100:8916-8920

Grace JB (1995) On the measurement of plant competition intensity. Ecology 76(1):305-308

Guo QX, Li JY, Zhang YX, Zhang JX, Lu DL, Korpelainen H, Li CY (2016) Species-specific competition and N fertilization regulate non-structural carbohydrate contents in two Larix species. For Ecol Manag 364:60-69

Han Y, Wang L, Zhang XL, Korpelainen H, Li CY (2013) Sexual differences in photosynthetic activity, ultrastructure and phytoremediation potential of Populus cathayana exposed to lead and drought. Tree Physiol 33:1043-1060

He J, Ma C, Ma Y, Li H, Kang J, Liu T, Polle A, Peng C, Luo ZB (2013) Cadmium tolerance in six poplar species. Environ Sci Pollut Res 20:163-174

Herrera CM (1988) Plant size, spacing patterns, and host-plant selection in Osyris quadripartita, a hemiparasitic dioecious shrub. J Ecol 76:995-1006

Hötscher M, Hay MJM (1997) Genotypic differences in physiological integration, morphological plasticity and utilization of phosphorus induced by variation in phosphate supply in Trifolium repens. J Ecol 85:341-350

Islam E, Liu D, Li T, Yang X, Jin X, Mahmood Q, Tian S, Li J (2008) Effect of $\mathrm{Pb}$ toxicity on leaf growth, physiology and ultrastructure in the two ecotypes of Elsholtzi aargyi. J Hazard Mater 154:914-926

Jiang H, Korpelainen H, Li CY (2013) Populus yunnanensis males adopt more efficient protective strategies than females to cope with excess zinc and acid rain. Chemosphere 91: $1213-1220$

Julkunen-Tiitto R (1985) Phenolic constituents in the leaves of northern willows-methods for the analysis of certain phenolics. J Agric Food Chem 33:213-217

Juvany M, Munné-Boch S (2015) Sex-related differences in stress tolerance in dioecious plants: a critical appraisal in a physiological context. J Exp Bot 66:6083-6092

Kalaji HM, Loboda T (2007) Photosystem II of barley seedlings under cadmium and lead stress. Plant Soil and. Environment 53:511-516

Kegge W, Pierik R (2010) Biogenic volatile organic compounds and plant competition. Trends Plant Sci 15:126-132

Korpelainen H (1991) Sex ratio variation and spatial segregation of the sexes in populations of Rumex acetosa and R. acetosella (Polygonaceae). Plant Syst Evol 174:183-195

Li CY, Xu G, Zang RG, Korpelainen H, Berninger F (2007) Sexrelated differences in leaf morphological and physiological responses of Hippophae rhamnoides along an altitudinal gradient. Tree Physiol 27:399-406

Liancourt P, Callaway RM, Michalet R (2005) Stress tolerance and competitive response ability determine the outcome of biotic interactions. Ecology 86:1611-1618

Lichtenthaler HK (1987) Chlorophylls and carotenoids: pigments of photosynthetic biomembranes. Methods Enzymol 148: 350-382

Liu X, Kozovits AR, Grams TEE, Blaschke H, Rennenberg H, Matyssek R (2004) Competition modifies effects of enhanced ozone/carbon dioxide concentrations on carbohydrate and biomass accumulation in juvenile Norway spruce and European beech. Tree Physiol 24:1045-1055

Llugany M, Tolra R, Martin SR, Poschenrieder C, Barcelo J (2013) Cadmium-induced changes in glutathione and phenolics of Thlaspi and Noccaea species differing in Cd accumulation. J Plant Nutr Soil Sci 176:851-858

Long SP, Bernacchi CJ (2003) Gas exchange measurements, what can they tell us about the underlying limitations to photosynthesis? Procedures and sources of error. J Exp Bot 54:23932401

Maestre FT, Callaway RM, Valladares F, Lortie CJ (2009) Refining the stress-gradient hypothesis for competition and facilitation in plant communities. J Ecol 97:199-205

Mayor JR, Wright SJ, Turner BL (2014) Species-specific responses of foliar nutrients to long-term nitrogen and phosphorus additions in a lowland tropical forest. J Ecol 102:36 44

McKane RB, Johnson LC, Shaver GR, Nadelhoffer KJ, Rastetter EB, Fry B, Giblin AE, Kielland K, Kwiatkowski BL, Laundre JA, Murray G (2002) Resource-based niches provide a basis for plant species diversity and dominance in arctic tundra. Nature 415:68-71 
Millard P, Way DA (2011) Tree competition and defense against herbivores: currency matters when counting the cost. Tree Physiol 31:579-581

Miller AE, Bowman WD, Suding KN (2007) Plant uptake of inorganic and organic nitrogen: neighbor identity matters. Ecology 88:1832-1840

Mitchell AK (1998) Acclimation of Pacific yew (Taxus brevifolia) foliage to sun and shade. Tree Physiol 18:749-757

Myers JA, Kitajima K (2007) Carbohydrate storage enhances seedling shade and stress tolerance in a neotropical forest. J Ecol 95:383-395

Nanami S, Kawaguchi H, Yamakura T (2005) Sex ratio and gender dependent neighboring effects in Podocarpus nagi, a dioecious tree. Plant Ecol 177:209-222

Nicotra AB (1999) Sexually dimorphic growth in the dioecious tropical shrub, Siparuna grandiflora. Funct Ecol 13:322-331

O'Brien MJ, Leuzinger S, Philipson CD, Tay J, Hector A (2014) Drought survival of tropical tree seedlings enhanced by nonstructural carbohydrate levels. Nat Clim Chang 4:710-714

Olsson T, Leverenz JW (1994) Non-uniform stomatal closure and the apparent convexity of the photosynthetic photon flux density response curve. Plant Cell Environ 17:701-710

Onyekwelu SS, Harper JL (1979) Sex ratio and niche differentiation in spinach (Spinacia oleracea L). Nature 282:609-611

Paul-Victor C, Zust T, Rees M, Kliebenstein DJ, Turnbull LA (2010) A new method for measuring relative growth rate can uncover the costs of defensive compounds in Arabidopsis thaliana. New Phytol 187:1102-1111

Prioul JL, Chartier P (1977) Partitioning of transfer and carboxylation components of intracellular resistance to photosynthetic $\mathrm{CO}_{2}$ fixation: a critical analysis of the methods used. Ann Bot 41:789-800

Qasim B, Motelica-Heino M, Bourgerie S, Gauthier A, Morabito D (2016) Rhizosphere effects of Populus euramericana Dorskamp on the mobility of $\mathrm{Zn}, \mathrm{Pb}$ and $\mathrm{Cd}$ in contaminated technosols. J Soils Sediments 16:811-820

Renner SS, Ricklefs RE (1995) Dioecy and its correlates in the flowering plants. Am J Bot 82:596-606

Rogers SR, Eppley SM (2012) Testing the interaction between inter-sexual competition and phosphorus availability in a dioecious grass. Botany 90:704-710
Sánchez-Vilas J, Turner A, Pannell JR (2011) Sexual dimorphism in intra- and inter-specific competitive ability of the dioecious herb Mercurialis annua. Plant Biol 13:218-222

Santiago LS, Wright SJ, Harms KE, Yavitt JB, Korine C, Garcia MN, Turner BL (2012) Tropical tree seedling growth responses to nitrogen, phosphorus and potassium addition. $\mathrm{J}$ Ecol 100:309-316

Secchi F, Zwieniecki MA (2011) Sensing embolism in xylem vessels: the role of sucrose as a trigger for refilling. Plant Cell Environ. 34:514-524

Shahid M, Pinelli E, Pourrut B, Silvestre J, Dumat C (2011) Leadinduced genotoxicity to Vicia faba L. roots in relation with metal cell uptake and initial speciation. Ecotoxicol Environ Saf 74:78-84

Stehlik I, Friedman J, Barrett SCH (2008) Environmental influence on primary sex ratio in a dioecious plant. Proc Natl Acad Sci U S A 105:10847-10852

Sterner RW, Elser JJ (2002) Ecological stoichiometry: the biology of elements from molecules to the biosphere. Princeton University Press, Princeton

Tilman D (1982) Resource competition and community structure. Princeton University Press, Princeton

Trinder CJ, Brooker RW, Davidson H, Robinson D (2012) Dynamic trajectories of growth and nitrogen capture by competing plants. New Phytol 193:948-958

Xu X, Yang F, Xiao XW, Zhang S, Korpelainen H, Li CY (2008) Sex-specific responses of Populus cathayana to drought and elevated temperatures. Plant Cell Environ 31:850-860

Yemm EW, Willis AJ (1954) The estimation of carbohydrates in plant extracts by anthrone. Biochem J 57:508-514

Zayed A, Gowthaman S, Terry N (1998) Phytoaccumulation of trace elements by wetland plants: I. Duckweed. J Environ Qual 27:715-721

Zhang CY, Zhao XH, Gao LS, Gadow K (2009) Gender, neighboring competition and habitat effects on the stem growth in dioecious Fraxinus mandshurica trees in a northern temperate forest. Ann For Sci 812:1-9

Zhang S, Jiang H, Zhao HX, Korpelainen H, Li CY (2014) Sexually different physiological responses of Populus cathayana to nitrogen and phosphorus deficiencies. Tree Physiol 34:343-354 